\title{
The Evasion of State Responsibility and the Lessons from Rwanda: The Need for a New Concept of Collective Security*
}

\section{OTTO HIERONYMI}

\section{Programme of International Rekations and Migration and Refugee Studies. Webster University, Geneva}

The political and intellectual mistakes committed by the victors and the vanquished after the First World War sowed the seeds of an even greater disaster twenty years later. Learning from the lessons of history, the systematic intellectual and political efforts and leadership that went into the development of international order after the Second World War have resulted, despite the cold war and the threat of communism, in an unprecedented period of peace and prosperity for the nations that have adhered to this order.

It has been evident for the last five years that no similar thinking, effort, and leadership have gone into developing a new, stable, 'post-communist' world order. Unless there is a radical change in this respect, the kind of radical change that was represented by the creation of NATO, the Marshall Plan, and European integration, there is a danger that we will waste a unique historic opportunity offered by the collapse of communism for a stable and equitable world order based on freedom, cooperation and mutual respect and new forms of collective security.

In fact, the 1990s have been marred so far by the revival of violent nationalism and ethnic strife, of which the tragedy in Rwanda is only one manifestation.

Today, there is widespread concern not only about the persistence of the existing conflicts, but also about the possible outbreak and multiplication of new ones in the future in various parts of the world, threatening enormous material devastation and hundreds of thousands, or millions, of potential victims.

In a technical sense, these conflicts are often of an internal character, nevertheless, they often also have an important cross-border dimension: changes in borders as a result of the conflict, the cross-border flight of refugees, and the sanctuary enjoyed by some of the planners and perpetrators of the violence.

*An earlier version of this paper was presented at a conference organized by Webster University in February 1996 on the theme 'Geneva and the Challenge of Humanitarian Action in the 1990s'. 
While each crisis has its own sources and dynamics -in former Yugoslavia, in the Great Lakes region of Africa, or in the CIS states-they also share some important common characteristics.

In most cases, 'internal wars' involve people who have for generations shared a common history and a common territory, and are often related by numerous other ties: they tend to be protracted, particularly violent and difficult to resolve. The conflict is the result of longstanding tensions and resentments between different groups, which the existing political structures have not been able to resolve in a peaceful manner. To raise the 'fighting spirit' of the population on either side, one can witness (as was the case in Rwanda) an escalation of mass propaganda involving the demonization of the 'opposite' group and calls for a 'life or death' struggle leading to the expulsion or physical elimination of the 'enemy': ethnic cleansing, rape, mass killings and ultimately genocide.

These violent conflicts can erupt suddenly, or may have been simmering for years or decades at varying levels of violence, as was the case in Rwanda and Burundi before 1994 and still remains the case today.

Whether the conflict is out in the open or not, in most cases there are unmistakable signs of the danger of the outbreak of widespread violence: ineffective, arbitrary and violent government, and armed opposition groups biding their time within the borders or in neighbouring countries to seize power and to perpetuate ineffective, arbitrary and violent government.

In fact, in the vast majority of cases, these wars are the direct or indirect result of bad government: of oppression, discrimination, corruption, and the inability of the political system to provide an adequate framework for the reconciliation of real or apparent conflicting interests and for the pursuit of common interests.

These conflicts involve a special type of evasion of state responsibility (and this was tragically illustrated in Rwanda): it is not necessarily the collapse of state structure, but also the systematic refusal to provide the state's protection to certain groups of the population. In contrast to 'traditional wars' between states, where people are the incidental victims of the conflict, in these fratricidal wars the people on the other side are the direct objectives of the violence. Hence the expulsions, the killings, the massed forced migrations and ultimately genocide, as people run amok with artificially and officially provoked hatred.

An important dimension of the evasion of state responsibility is the inability or unwillingness of the international community, of neighbouring and other countries, to help avoid and to end the conflict and to help create the conditions for lasting peace and reconciliation. Despite outbreaks of fighting and large-scale massacres in Burundi and in the region even before the Rwandan crisis, the international commumity made no serious effort to halt the violence and try to bring about long term solutions. After civil war broke out in Rwanda in October 1990, strenuous efforts were made in the region, at the Arusha negotiations, to bring about a cease-fire and an agreement on powersharing. This was, however, not matched by any equal commitment on the part 
of the UN and the richer states to secure and enforce the peace. This neglect was motivated by the internal and regional (hence 'unimportant') character of the crisis, and by explicit or implicit reference to the principle of national sovereignty.

Yet Rwanda and Yugoslavia have amply demonstrated that it is dangerous and irresponsible to dismiss these conflicts, and the threat of new ones, as purely internal or regional affairs; ultimately they represent a major threat to international order, for the neighbouring countries as well as for the international community at large.

These conflicts present a major political, military, economic and social challenge, requiring an increased 'threat perception' both by neighbours and by the international community. Yet the search for solutions-whether in the Great Lakes region of Africa or in the former Yugoslavia-is rendered both imperative and especially difficult, because of the fratricidal character of these wars and because the people involved in the fighting will have to continue to live together in the future.

These conflicts have also shown how hollow the reference to state sovereignty has become: it is invoked by the instigators and perpetrators of violence to justify their actions and to claim impunity, and it is cited by the international community to explain its lack of concern and commitment.

Sovereignty, like nationalism, has been one of the most abused political concepts in the twentieth century. Unlimited sovereignty, not restrained by respect for law and human dignity and freedom, leads to reckless external aggression and domestically to widespread oppression.

Evasion of state responsibility in most cases does not mean the "lack of sovereign power', but the violent and widespread abuse of sovereignty. It means the abusive and selective exercise of sovereignty: the denial of the obligation implied in sovereignty to provide protection and good government to all citizens of a country.

The abuse of domestic sovereignty is not a purely domestic matter. The expressions 'humanitarian intervention' and the 'collapse of state authority' do not really deal with the full issue; the term 'humanitarian intervention' tends to imply a short-term rather than a lasting concern, while 'the collapse of state authority' implies that only this justifies the intervention.

The traditional concept of collective security has to do with external relations, with the right to wage war. Basically, collective security means the limitations of sovereignty to commit acts of aggression.

Yet collective security also has a domestic dimension: the collective right and duty to prevent the spreading of 'domestic cancers', of totalitarian regimes or anarchy. The new tradition of collective security as developed in the Atlantic community, among the OECD countries, and in Western Europe, has been as important in maintaining peace and prosperity as nuclear deterrence.

A new approach should and can be developed in order to deal with these seemingly intractable situations and bring about a lasting solution. Such an approach ought to be based on the explicit recognition that the quality of a 
domestic political system is an internationally relevant matter and the evasion of fundamental state responsibilities is an issue of legitimate concern to a country's international partners. This concept goes beyond the idea of 'humanitarian intervention', which essentially implies concern and action once a crisis has erupted. It is also different from the idea of 'trusteeship' for 'collapsed states'. The proposed approach implies a long-term common concern and commitment for 'good government' in a given region. This commitment implies both solidarity and help in achieving 'good government', and potential sanctions and collective intervention to forestall the spreading of 'domestic political cancers'. In order to be effective and acceptable, it has to be based both on shared values (including the belief that war and violence are not the solution) and on a minimum of common strength and resources. It is also important that this commitment should include the countries of a region as well as outside powers sharing the same objectives in the development of stable and prosperous democratic societies.

This approach, which could be called the 'domestic dimension of collective security', could be inspired by the experience during the last half century of the countries of Western Europe and of the Atlantic-Pacific community. It may be argued that such an approach could have forestalled the tragedy in Rwanda, and is the only one that can provide a ray of hope for success in that region today.

Unless we succeed in extending this peaceful concept of collective security, which involves the upholding of human rights and freedoms and the creation of stable frameworks for complex multiethnic societies, to countries threatened by outbursts of violent nationalism, by ethnic strife and fratricidal wars, forced migration will remain a growing threat to millions of potential victims and to the peace and stability of rich and poor countries alike. 